\title{
Inflammatory Myofibroblastic Pseudotumour of the Urinary Bladder in a Young Male: A Case Report
}

\section{Genç Hastada Mesanenin Enflamatuvar Miyofibroblastik Psodotümörü: Olgu Sunumu}

\author{
(D) Salih Budak1, (D) Erdem Kısa1, (D) Cem Yücel1, (D) Sümeyye Ekmekçi2, (D) Çelik Orçun1 \\ 1 University of Health Sciences Tepecik Training and Research Hospital, Clinic of Urology, Izmir, Turkiye \\ 2University of Health Sciences Tepecik Training and Research Hospital, Clinic of Pathology, Izmir, Turkiye
}

\begin{abstract}
Inflammatory myofibroblastic tumours (IMTs) are relatively rare entities with an uncertain pathogenesis and are classified as tumours of intermediate biological potential. IMTs of the urinary bladder are generally benign in nature and have a very small risk of distant metastasis. Radiographic imaging and clinical symptoms are not helpful in identifying these tumours, because of their nonspecific features similar to those of malignant tumours. Surgical excision may be sufficient for treating patients with urinary bladder IMT.
\end{abstract}

Keywords: Inflammatory myofibroblastic tumour, Urinary bladder, Bladder neoplasm

Öz

Enflamatuvar miyofibroblastik tümör (EMT) belirsiz bir patogenez ile nispeten nadir görülen ve ara biyolojik potansiyeli tümörler olarak sınıflandırılır. Mesane IMT'leri genellikle çok iyi huylu bir hastalık seyri gösterir ve çok düşük bir uzak metastaz oranına sahiptir. Radyografik görüntüleme ve klinik semptomlar, bu tümörlerin malign tümörlerdekine benzer spesifik olmayan özellikleri nedeniyle tanımlanmasında faydasızdır. Komple cerrahi eksizyon mesane EMT'yi tedavi etmek için yeterli olabilir.

Anahtar Kelimeler: Enflamatuvar miyofibroblastik tümörs, Mesane, Mesane tümörü

\section{Introduction}

Inflammatory myofibroblastic pseudotumors (IMT) are rare spindle cell tumors, most commonly affecting the lungs (1). The urinary bladder is the IMT site in many cases, but such tumors in Asian populations are extremely rare, with only 15 cases having been reported (2). The bladder is the most commonly affected site in the genitourinary system (2). It is not clear whether IMT is an inflammatory process or a true neoplasm, as the risk of distant metastasis is very low whereas local invasion is common (3). IMTs of the urinary blad-der are difficult to distinguish from other proliferating and malig $\neg$ nant spindle cells (3). The most common malignancies in the urinary bladder include sarcomatoid carcinoma and leiomyosarcoma. Since IMTs are controlled by local treatment, differential diagnosis is important and can help avoid unnecessary aggressive treatments (e.g. radical cystectomy, adjuvant radiation or chemotherapy). Herein, we present a patient with IMT of the urinary bladder who was successfully treated with local excision.

\section{Case Presentation}

A 23-year-old male university student was admitted with the complaints of suprapubic pain, weight loss in the past two months and macroscopic haematuria. The patient reported no other complaints, such as anorexia or fever. No medical history of bladder surgery, urinary tract infection, trauma or autoimmune disease was noted. Haematological and biochemical findings were within the normal range. A $7 \times 6 \mathrm{~cm}$ solid lesion confined to the bladder was detected, and no metastatic lesion was encountered on a thoraco-abdominal computed tomography scan taken for staging purposes (Figure 1A-1B). A non-papillary,

Correspondence: Erdem Kısa MD, University of Health Sciences Tepecik Training and Research Hospital, Clinic of Urology, İzmir, Turkiye

Phone: +90 5052234221 E-mail: drerdemkisa@hotmail.com ORCID-ID: orcid.org/0000-0001-5130-4483

Received: 01.31.2019

Accepted: 07.20.2019

Cite this article as: Budak S, Kısa E, Yücel C, Ekmekçi S, Orçun Ç. Inflammatory Myofibroblastic Pseudotumour of the Urinary Bladder in a Young Male: A Case Report. J Urol Surg 2019;6(4):328-330

${ }^{\circ}$ Copyright 2019 by the Association of Urological Surgery / Journal of Urological Surgery published by Galenos Publishing House. 
wide based, solid $7 \times 6 \mathrm{~cm}$ tumour (Figure 2) with excessive vascularity in the lateral bladder wall and apex was resected viabipolar transurethralresection (TUR) of the bladder tumour (Figure 3) with the patient under spinal anaesthesia;the tumour base was sampled separately. In the TUR- bladder material, the tumour consists of myofibroblastic and fibroblastic spindle cells with inflammatory cells (Figure 4A). Immunohistochemical positive staining for actin was detected in the tumour cells and weak staining for anaplastic lymphoma kinase (ALK) was observed in the cells (Figure 4B). In the open partial cystectomy, tumour cells were similar to those of the TUR-bladder material and the final diagnosis was IMT limited to the mucosal layer of the bladder.

The tumor consisted of fusiform cells spread over a fibrotic inflammatory base. The patient was diagnosed with IMT. Open partial cystectomy was performed in accordance with the pathological results to achieve local control (Figure 1B) and to remove the myofibroblastic pseudotumor exceeding the muscular layer of the bladder to reach the serosa, and remained intact but was confined to the mucosal layer of the bladder. The patient remained recurrence-free for 36 months after surgery.

\section{Discussion}

IMT of the bladder was first defined by Roth (4) in 1980 in a 32-year-old female patient. These tumors are mostly encountered in the lungs, retroperitoneum, mesentery, liver, spleen and small intestines, and rarely in the bladder $(5,6)$. They can occur at any age, but typically appear in young adults. IMT of the bladder is more frequent in males, and the femalemale ratio is about 1:3 (7). Several predisposing factors for IMT have been described, with possible aetiologies including chronic irritation, trauma, autoimmune disease and infectious organisms, but the aetiological factors are unclear $(1,3,8)$. The present case had no medical history related to any predisposing factor and was successfully treated with local excision.

The histological diagnosis of IMT may be confused with sarcoma because of the appearance of spindle cells and inflammatory infiltration. However, IMTs have no atypical mitotic cells and mostly stain positive for ALK. This staining characteristic can be used to distinguish between IMT and sarcomas in the differential diagnosis of suspected cases (9). ALK positivity is helpful if present, but its absence does not exclude the diagnosis of IMT, particularly in adults (3). Patients present with haematuria, abdominal pain and weight loss. It is difficult to distinguish an IMT from a malignant tumor by imaging techniques (6). In our case, the IMT appeared similar to an invasive malignant tumor and displayed infiltration from the sides.

Despite the low risk of distant metastasis in cases of IMT of the urinary bladder, local recurrence is seen in 25\% of cases (10). IMT treatment requires close clinical follow-up due to the unknown biological behaviour of these tumors. Surgical resection is the standard approach for treating IMT of the urinary bladder (2). However, Kim et al. (11) reported an uncommon case of recurrent IMT of the urinary bladder with showing malignant transformation and multiple metastases. In addition, since recurrence of bladder IMT after complete surgical resection has not been reported in the literature, partial cystectomy is recommended (12). The preferred treatment is total excision of the tumor due to local recurrence risk, however radical cystectomy is not necessary $(5,13)$. At the 36 -month followup after partial cystectomy, our patient was free of recurrence ard symptoms. Aggressive therapy (radical cystectomy, adjuvint radiation therapy or chemotherapy) should be avoided in these patients because of the benign clinical course in the majority of cases.

It is difficult to differentiate IMTs from benign tumors from IMT by physical examination and radiological methods. Although these tumors appear to be histopathologically malignant, they grow slowly, and malignant transformation and metastasis rarely occur. Distinguishing IMT from other sarcomatoid carcinomas is essential. The general treatment approach is a local, organ-

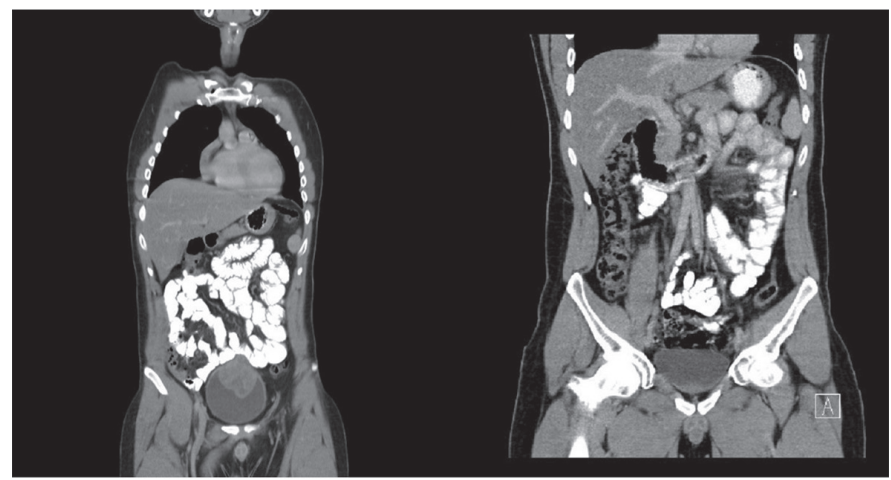

Figure 1. A) Contrast-enhanced computed tomography (CT) image showing a $7 \times 6 \mathrm{~cm}$ mass on the lateral side and apex of the urinary bladder. B) Contrastenhanced CT image after partial cystectomy

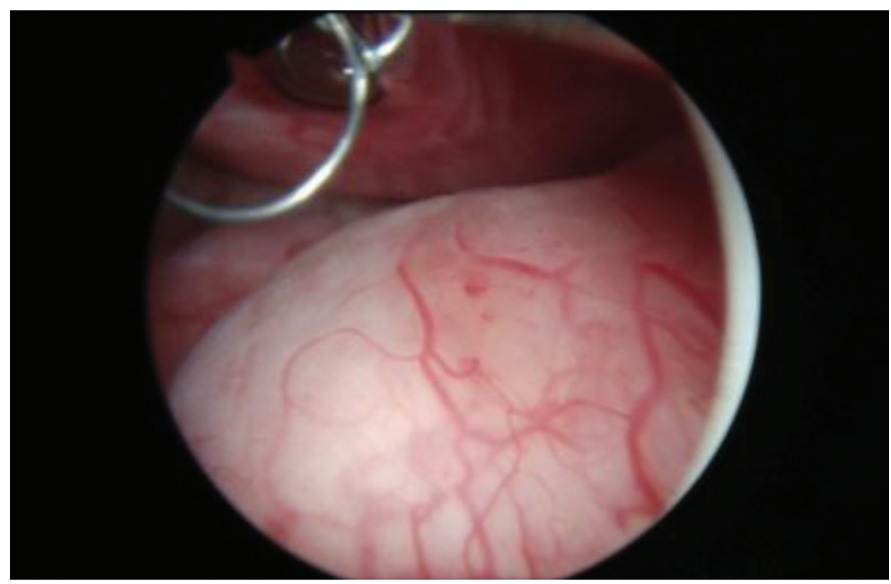

Figure 2. Cystoscopic image of $7 \mathrm{~cm}$, well-circumscribed tumor in the bladder 


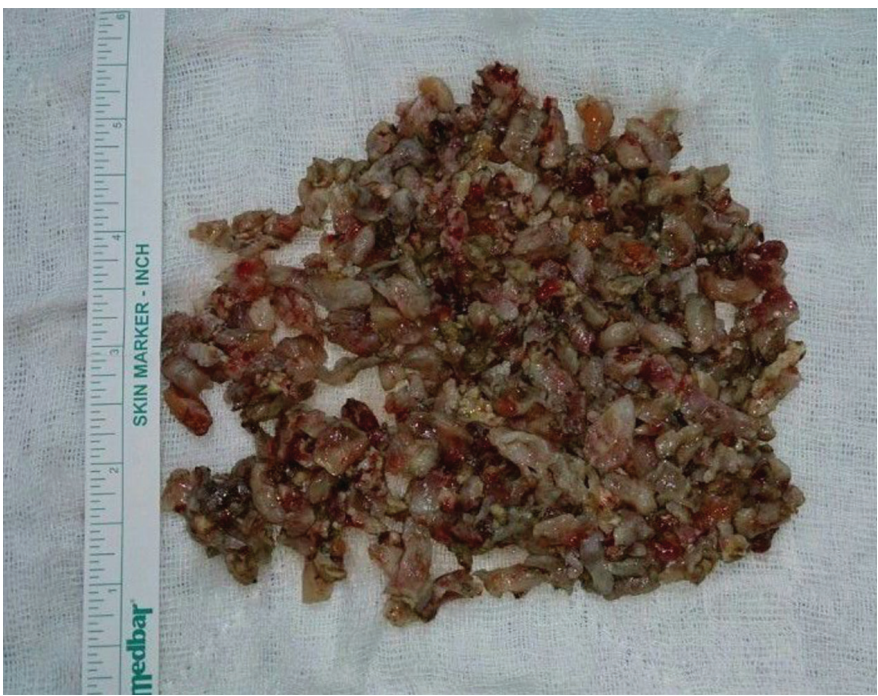

Figure 3. Macroscopic image of the curetted material resected endoscopically within the bladder

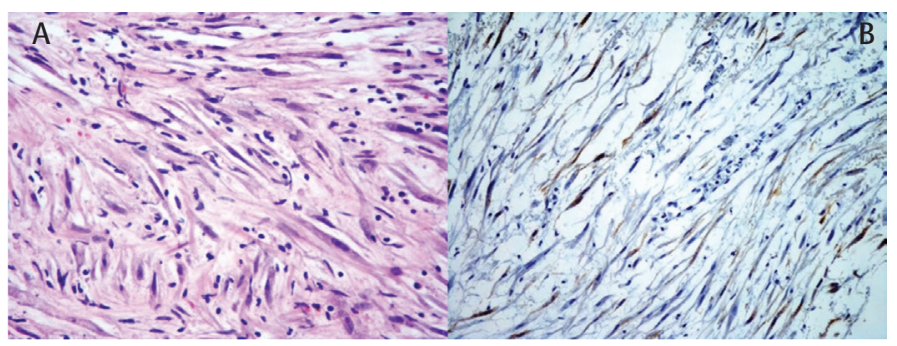

Figure 4. A) Tumour cells and associated inflammatory cell infiltration (haematoxylin and eosin, ×400). B) Weak anaplastic lymphoma kinase staining oftumour cells $(\times 200)$

preserving excision and close monitoring. In this study, we discussed a 23-year-old male patient who was admitted to the clinic with the complaints of macroscopic haematuria and diagnosed with an IMT.

\section{Ethics}

Informed Consent: Written informed consent was obtained from the patient.

Peer-review: Externally peer-reviewed.

\section{Authorship Contributions}

Concept: S.B., C.Y., E.K., Data Collection and/or Processing: S.B., E.K., S.E., Analysis and/or Interpretation: S.B., S.E., E.K., C.Y., Ç.O., Literature Research: S.B., Writing: S.B., E.K.
Conflict of Interest: No conflict of interest was declared by the authors.

Financial Disclosure: The authors declared that this study received no financial support.

\section{References}

1. Coffin CM, Watterson J, Priest JR, Dehner LP. Extrapulmonary inflammatory myofibroblastic tumor (inflammatory pseudotumor). A clinicopathologic and immunohistochemical study of 84 cases. Am J SurgPathol 1995;19:859872.

2. Teoh JYC, Chan NH, Mak S, Lo MA, Leung WI, Hui CY, Law IC, Fan CW, Cheung FK, Chan SW, Yiu MK, Man CW, So HS, Cheung HY, Hou SS, Ng CF. Inflammatorymyofibroblastictumours of theurinarybladder: multi-centre 18-year experience. Urol Int 2015;94:31-36.

3. Gleason BC, Hornick JL. Inflammatorymyofibroblastictumours: Wherearewenow? J Clin Pathol 2008;61:428-437.

4. Roth JA. Reactive pseudosarcomatous response in urinary bladder. Urology 1980;16:635-637.

5. Kondo T, Kawahara T, Chiba S, Ohtaka M, Kumano Y, Saitoh Y, Mochizuki T, Hattori $Y$, Teranishi Jl, Miyoshi Y, Yumura Y, Yao M, Inayama Y, Uemura H. InflammatoryMyofibroblasticTumor in theBladder: A Case Report. Case Rep Oncol 2016;9:554-558.

6. Tao YL, Wang ZJ, Han JG, Wei P.Inflammatory myofibroblastictumorsuccess fully treatedwithchemotherapyandnonsteroidals: a case report. World J Gastroenterol 2012;18:7100-7103.

7. Harik LR, Merino $C$, Coindre JM, Amin MB, Pedeutour $F$, Weiss SW. Pseudosarcomatousmyofibroblasticproliferations of thebladder: A clinicopathologicstudy of 42 cases. Am J Surg Pathol 2006;30:787-794.

8. Alderman M, Kunju LP. Inflammatorymyofibroblastictumor of thebladder. Arch Pathol Lab Med 2014;138:1272-1277.

9. Emerson RE, Cheng L. Immunohistochemical markers in the evaluation of tumors of the urinary bladder: a review. Anal Quant Cytol Histol 2005;27:301-316.

10. Coffin CM, Fletcher JA. In: World HealthOrganizationclassification of tumours: pathologyandgenetics of tumours of softtissueand bone. Fletcher CD, Unni KK, Mertens F, editors. Lyon: IARC Press; 2002. pp. 91-93.

11. Kim HW, Choi YH, Kang SM, Ku JY, Ahn JH, Kim JM, Chung JM, Ha HK, Chung MK. Malignant inflammatory myofibroblastic tumor of the bladder with rapid progression. Korean J Urol 2012;53:657-661.

12. Nkwam N, Johnson B, Bazo A, McCulloch TA, Mann GS. Inflammatory myofibroblastic tumour of the urinary bladder managed with partial cystectomy: a case report \& literature review. J Surg Case Rep 2016;2016. pii: rjw181.

13. Cheng L, Foster SR, MacLennan GT, Lopez-Beltran A, Zhang S, Montironi R. Inflammatory myofibroblastic tumors of the genitourinary tract--single entity or continuum? J Urol 2008;180:1235-1240. 